\title{
РЕСУРСНАЯ ИНВЕСТИЦИОННАЯ ПОЛИТИКА РОССИЙСКИХ КРЕДИТНЫХ ОРГАНИЗАЦИЙ В УСЛОВИЯХ ЭКОНОМИЧЕСКИХ САНКЦИЙ
}

\begin{abstract}
АНнотАция. Начиная с перехода к рыночным преобразованиям экономика России остается непростой, переживая то большие, то меньшие трудности. Принятие в 2014 г. западных экономических санкций осложнило решение многих экономических и, как следствие, социальных задач. В достаточно сложной ситуации оказались отечественные кредитные организации: к потере внешних источников финансирования добавилась проблема невозврата кредита, вызванная в том числе неплатежеспособностью населения и мелкого бизнеса. В статье приводятся официальные статистические данные об объемах средств, привлеченных и инвестированных российскими кредитными организациями за последние три года работы в условиях экономических санкций. Представлено изменение состава и структуры ресурсов, привлеченных и инвестированных кредитными организациями. Анализируется динамика доходов кредитных организаций за рассматриваемые годы.

КЛЮчЕВЫЕ СЛОВА. Кредитные организации; ресурсы; привлеченные средства; инвестиции; доходы.

ИНФОРМАЦИЯ О СТАТЬЕ. Дата поступления 29 апреля 2016 г.; дата принятия к печати 7 июня 2016 г.; дата онлайн-размещения 22 июля 2016 г.
\end{abstract}

I. V. Dubovik

Baikal State University, Irkutsk, Russian Federation

\section{RESOURCE-BASED INVESTMENT POLICY \\ OF RUSSIAN CREDIT ORGANIZATIONS IN TERMS OF ECONOMIC SANCTIONS}

\begin{abstract}
Since the transition to market reforms, Russia's economy remains challenging, experiencing either big or small difficulties. Adoption in 2014 of western economic sanctions has complicated solution of many economic and, as a consequence, social problems. Domestic credit organizations are facing a rather complicated situation: the loss of external funding sources has been added by the problem of credit non-repayment caused as well by financial insolvency of the population and small business. The article brings forth the official statistics on volumes of funds attracted and invested by Russian credit organizations during the past three years in terms of economic sanctions. It presents the changes in composition and structure of the resources attracted and invested by credit organizations. It analyzes the dynamics of credit organizations' income in the course of the years considered.

KEYWORDS. Credit organizations; resources; attracted funds; investments; incomes. ARTICLE INFO. Received April 29, 2016; accepted June 7, 2016; available online July $22,2016$.
\end{abstract}

Уже третий год Россия живет в условиях внешних экономических санкций, которые, наложившись на внутренние проблемы, привели к кризисному состоянию отечественной экономики. Наиболее остро сложившаяся ситуация сказалась на кредитных организациях, так как резко ограничила их доступ к источникам, необходимым для деятельности ресурсов, что усугубилось также ростом процентных ставок.

(c) И. В. Дубовик, 2016

\section{Baikal Research Journal}

электронный научный журнал Байкальского государственного университета 
Вместе с тем, судя по последним заявлениям представителей Банка России, регулятор считает, что кредитные организации адаптировались в нынешних условиях и им хватает ликвидности для кредитования экономики. В связи с чем представляется интересным провести анализ ресурсной политики кредитных организаций и политики по использованию ресурсов за последние три года, включая предсанкционный, 2013 г. Отметим, что подобный анализ сроком в 10 лет (начиная с 2002 г.), проводился нами ранее в соавторстве с М. Е. Горчаковой [1].

Рассмотрим динамику ресурсов кредитных организаций, которые состоят из собственных и привлеченных средств. Отметим, что собственный капитал кредитных организаций в течение анализируемого периода растет: в 2013 г. - на 7,4 и $7,6 \%$ по полугодиям; в 2014 г. - на 4,3 и 7,6 \% соответственно; в 2015 г. - на 3,0 и 10,3 \% (табл. 1). Снижение темпов прироста наблюдается в 1-м полугодии 2014 и 2015 гг. Наибольший прирост собственных средств кредитных организаций произошел во 2-м полугодии 2016 г. Всего за три года собственные средства кредитных организаций выросли на $37,2 \%$.

Таблица 1

Собственные средства российских кредитных организаций в 2013-2016 г2., млрд р.

\begin{tabular}{|l|r|r|r|r|r|r|r|}
\hline \multirow{2}{*}{ Показатель } & \multicolumn{2}{|c|}{2013} & \multicolumn{2}{c|}{2014} & \multicolumn{2}{c|}{2015} & \multicolumn{1}{c|}{2016} \\
\cline { 2 - 8 } & \multicolumn{1}{|c|}{01.01} & \multicolumn{1}{c|}{01.07} & 01.01 & \multicolumn{1}{c|}{01.07} & 01.01 & \multicolumn{1}{c|}{01.07} & \multicolumn{1}{c|}{01.01} \\
\hline Средства организаций & 6112,9 & 6567,6 & 7064,3 & 7370,2 & 7928,4 & 8166,4 & 9008,6 \\
\hline Изменение капитала, \% & - & $+7,4$ & $+7,6$ & $+4,3$ & $+7,6$ & $+3,0$ & $+10,3$ \\
\hline
\end{tabular}

Составлено по: URL : http://www.cbr.ru/publ/BBS/Bbs1312r.pdf; URL : http://www.cbr.ru/publ/ BBS/Bbs1412r.pdf; URL : http://www.cbr.ru/publ/BBS/Bbs1512r.pdf; URL : http://www.cbr.ru/publ/ BBS/Bbs1602r.pdf.

По заявлению Э. Набиуллиной, за январь-февраль 2016 г. капитал банков вырос на $0,9 \%$ до 9,1 трлн р. В итоге, по данным на март 2016 г., у банковского сектора сохраняется значительный запас совокупного капитала $-1,8$ трлн р., который позволяет наращивать кредитование экономики ${ }^{1}$.

Следует заметить, что среди источников открытых публикаций отсутствуют данные о суммарных размерах уставного капитала кредитных организаций, входящего, как известно, в состав собственных средств. Вместе с тем данная информация с позиции формирования ресурсов представляет большой интерес, так как уставный капитал - это те денежные средства, которые привлечены банками на рынке акций, и напрямую не зависят от результатов их деятельности, в отличие, например, от размеров прибыли - другой части собственного капитала. Даже учитывая тот факт, что прирост уставного капитала может быть вызван необходимостью соответствовать требованиям регулятора, динамику уставного капитала кредитных организаций можно считать проявлением их ресурсной политики. Получить представление об уставном капитале кредитных организаций можно косвенно через показатели прироста уставного капитала и эмиссионного дохода, данных о проведенных IPO/SPO и т. д. [2]. В настоящей статье дальнейший анализ деятельности кредитных организаций по привлечению ресурсов будет проведен по составу и структуре обязательств.

Обязательства кредитных организаций в соответствии с банковской терминологией включают в себя заемные и привлеченные средства. Однако и те, и другие являются результатом целенаправленной деятельности банков по привлечению денежных средств, также как и те, и другие средства банки получают на единой срочной, возвратной и платной основе. Для удобства дальнейшего аналитического

${ }^{1}$ URL : https://www.news.mail.ru/economics/25386409/?frommail=1.

\section{Baikal Research Journal}

электронный научный журнал Байкальского государственного университета 
обзора все обязательства кредитных организаций поэтому будут называться привлеченными средствами.

Объем средств, привлеченных кредитными организациями за последние три года, неуклонно растет (табл. 2). В целом, с 1 января 2013 г. по 1 января 2016 г. прирост составил около $69 \%$. Единственное заметное снижение $(12 \%)$ произошло только за 1-е полугодие 2014 г., и оно совпало с началом введения антироссийских санкций. Однако за 2 -е полугодие 2014 г. прирост средств составил 36 \% , что привело к восстановлению повышательной тенденции.

Таблица 2

Средства, привлеченные российскими кредитными организациями, в 2013-2016 г2., трлн р.*

\begin{tabular}{|l|r|r|r|r|r|r|r|}
\hline \multirow{2}{*}{ Привлеченные средства } & \multicolumn{2}{|c|}{2013} & \multicolumn{2}{|c|}{2014} & \multicolumn{2}{|c|}{2015} & \multicolumn{1}{c|}{2016} \\
\cline { 2 - 8 } & 01.01 & 01.07 & 01.01 & 01.07 & 01.01 & 01.07 & 01.01 \\
\hline Вклады физических лиц: & 14,25 & 15,63 & 16,96 & 16,88 & 18,56 & 19,89 & 23,22 \\
р. & 11,76 & 12,83 & 14,00 & 13,70 & 13,71 & 14,81 & 16,40 \\
иностранная валюта & 2,49 & 2,80 & 2,96 & 3,18 & 4,85 & 5,08 & 6,82 \\
\hline Депозиты организаций и индивидуаль- & 9,79 & 10,67 & 13,50 & 9,68 & 16,49 & 16,69 & 19,25 \\
ных предприятий: & & & & & & & \\
р. & 6,26 & 6,63 & 6,56 & 4,65 & 8,64 & 8,73 & 8,73 \\
иностранная валюта & 3,53 & 4,04 & 6,94 & 5,03 & 7,85 & 7,96 & 10,52 \\
\hline Депозиты кредитных организаций: & 4,74 & 4,79 & 5,38 & 4,77 & 6,59 & 4,96 & 7,09 \\
р. & 2,53 & 2,33 & 2,37 & 2,44 & 3,22 & 2,55 & 3,69 \\
иностранная валюта & 2,21 & 2,46 & 3,01 & 2,33 & 3,37 & 2,41 & 3,40 \\
\hline Объем выпущенных сертификатов & 0,23 & 0,32 & 0,36 & 0,35 & 0,47 & 0,55 & 0,57 \\
\hline Объем выпущенных облигаций & 1,04 & 1,13 & 1,21 & 1,20 & 1,36 & 1,33 & 1,27 \\
\hline Объем средств, привлеченных произво- & 0,14 & 0,17 & 0,13 & 0,23 & 1,95 & 0,87 & 0,88 \\
дными финансовыми инструментами & & & & & & & \\
\hline Объем средств, привлеченных выпу- & 1,15 & 1,23 & 1,01 & 0,86 & 0,89 & 0,64 & 0,69 \\
ском векселей: & & & & & & & \\
р. & 0,73 & 0,72 & 0,62 & 0,55 & 0,49 & 0,38 & 0,36 \\
иностранная валюта & 0,42 & 0,51 & 0,39 & 0,31 & 0,40 & 0,26 & 0,33 \\
\hline Всего & 31,34 & 33,94 & 38,55 & 33,97 & 46,31 & 44,93 & 53,54 \\
\hline
\end{tabular}

* Выпущенные сертификаты включают депозитные и сберегательные сертификаты, объем выпуска которых соотносится в среднем, как 1:60-1:180.

Составлено по: URL : http://www.cbr.ru/publ/BBS/Bbs1312r.pdf; URL : http://www.cbr.ru/publ/ BBS/Bbs1412r.pdf; URL : http://www.cbr.ru/publ/BBS/Bbs1512r.pdf; URL : http://www.cbr.ru/publ/ BBS/Bbs1602r.pdf.

Объем вкладов физических лиц за три года вырос до 23,22 трлн р., что почти на $63 \%$ превысило объем вкладов на 1 января 2013 г. Прирост в рублях составил $39,5 \%$, а в валюте - $174 \%$. Преобладающий темп прироста вкладов в валюте наблюдается с 2014 г., что также можно связать с введением санкций и с их следствием - усугублением имеющихся экономических проблем. Ведь общеизвестно, что население при нарастании социально-экономических рисков предпочитает хранить свои сбережения в конвертируемой валюте. По прогнозу Агентства по страхованию вкладов, объем вкладов населения в 2016 г. увеличится на 3,3-3,7 трлн р., или на $14-16 \%$. В результате к концу года вклады вырастут до $26,5-26,9$ трлн р. ${ }^{2}$

Объем депозитов организаций и индивидуальных предпринимателей (ИП) прирос за три года на 96,6 \% (см. табл. 2). Общая тенденция совпадает с тенденцией вкладов физических лиц: некоторый спад в 2014 г. и восстановление в последующий период. Прирост рублевых депозитов составил 39,5 \% , тогда как валютные депозиты приросли на 198 \% , т. е. почти вдвое. При этом, если на 1 января 2013 г. де-

${ }^{2}$ URL : https//bankir.ru/novosti/20160329/.

\section{Baikal Research Journal}


позиты организаций и ИП в рублях на 77 \% превышали валютные депозиты, то на 1 января 2016 г. ситуация поменялась на обратную: объем валютных депозитов на 20,5 \% превысил рублевые. Динамика объема депозитов кредитных организаций в привлеченных средствах выглядит ровнее. Трехлетний прирост составил $50 \%$, в том числе в рублях $-46 \%$, а в валюте $-54 \%$. При этом общая повышательная тенденция в течение анализируемого периода имеет волнообразный характер.

Средства от продажи депозитных и сберегательных сертификатов привлекались по полугодиям неравномерно: в 1-м полугодии 2013 г. прирост составил $39 \%$; во 2 -м полугодии 2013 г. - $12,5 \%$; во 2 -м полугодии 2014 г. $-34 \%$; в 1 -м полугодии 2015 г. - $17 \%$; во 2 -м полугодии 2015 г. - 3,6 \%. Всего за три года объем выпущенных кредитными организациями сертификатов вырос на $147,8 \%$, или почти в 2,5 раза. Прирост средств от продажи облигаций наблюдается в 2013 г. (на 8,7 и $7,1 \%$ по полугодиям) и во 2 -м полугодии 2014 г. (на $13,3 \%$ ). В течение 2015 г. объем средств, привлеченных банками от продажи облигаций, снижается. Этот факт косвенно может свидетельствовать о неблагополучной ситуации на фондовом рынке: росте стоимости ресурсов (ставок), снижении числа консервативных инвесторов.

Обращает на себя внимание динамика объема средств, привлеченных кредитными организациями на срочном рынке. Наибольший прирост средств от игры с производными финансовыми инструментами (ПФИ) произошел в 2014 г. (на 77 \% в 1-м полугодии и в 8,5 раз во 2-м полугодии). Из этого можно сделать два вывода. Во-первых, банки демонстрируют высокий профессионализм, который требуется для работы на срочном рынке. Во-вторых, учитывая некоторое «затишье» на других сегментах фондового рынка, а также снижение темпов прироста средств во вклады и депозиты, банки активизировали деятельность на высокорисковом срочном рынке, показывая тем самым гибкость своей ресурсной политики. В результате объем средств, привлеченных ПФИ, на 1 января 2016 г. в 6,3 раза превысил аналогичный показатель 1 января 2013 г.

Объем средств, привлеченных выпуском векселей, в отличие от других статей, показал снижение, которое началось с 2014 г. (см. табл. 2). Понижательная тенденция касается привлечения средств от продажи как рублевых, так и валютных векселей. Общее снижение за три года составило $40 \%$, в том числе по рублевым векселям $51 \%$, по валютным векселям - 21,4\%. В связи с чем можно предположить снижение доверия населения к такому инструменту, как вексель, на фоне массового отзыва банковских лицензий и выплаты страхового возмещения только по вкладам.

В течение анализируемого периода в объеме привлеченных кредитными организациями средств преобладают вклады физических лиц - от 40 до 50 \% всех средств (табл. 3). На втором месте стабильно присутствуют депозиты организаций и индивидуальных предпринимателей. Их доля колеблется от 29 до $37 \%$ всех привлеченных средств. Долю от 11 до $15 \%$ занимают депозиты кредитных организаций. Всего в структуре привлеченных средств вклады (депозиты) занимают не менее $90 \%$ : около $92 \%$ — в 2013 г., 92-93\% — в 2014 г., 90-93\% — в 2015 г. На 1 января 2016 г. доля вкладов (депозитов) в структуре привлеченных средств составила 93,5 \% - максимальное значение за анализируемый период. Исходя из чего следует отметить, что средства, привлеченные кредитными организациями с помощью таких инструментов, как ценные бумаги, играют крайне незначительную роль в их ресурсной базе. В течение трех лет доля сертификатов в структуре привлеченных средств оставалась почти неизменной - около $1 \%$. Доля облигаций за три года снизилась на 9 \% , заняв в структуре привлеченных средств $2,4 \%$ на 1 января 2016 г. Доля векселей за три года снизилась почти в 3 раза (до 1,3\% на начало текущего года). В то же время в 3,4 раза выросла доля производных финансовых инструментов, однако данные инструменты на 1 января 2016 г. занимают в общем объеме привлеченных средств менее $2 \%$.

\section{Baikal Research Journal}


Таблица 3

Структура средств, привлеченных российскили кредитныли организацияли

\begin{tabular}{|c|c|c|c|c|c|c|c|}
\hline \multirow[t]{2}{*}{ Привлеченные средства } & \multicolumn{2}{|c|}{2013} & \multicolumn{2}{|c|}{2014} & \multicolumn{2}{|c|}{2015} & 2016 \\
\hline & 01.01 & 01.07 & 01.01 & 01.07 & 01.01 & 01.07 & 01.01 \\
\hline Вклады физических лиц, всего & 45,5 & 46,1 & 44,0 & 49,7 & 40,1 & 44,3 & 43,8 \\
\hline $\begin{array}{l}\text { Депозиты организаций и индивидуальных } \\
\text { предприятий, всего }\end{array}$ & 31,2 & 31,4 & 35,0 & 28,5 & 35,6 & 37,2 & 36,3 \\
\hline Депозиты кредитных организаций, всего & 15,1 & 14,1 & 14,0 & 14,1 & 14,2 & 11,0 & 13,4 \\
\hline Объем выпущенных сертификатов & 0,7 & 1,0 & 1,0 & 1,0 & 1,0 & 1,2 & 1,1 \\
\hline Объем выпущенных облигаций & 3,3 & 3,3 & 3,1 & 3,5 & 3,0 & 3,0 & 2,4 \\
\hline $\begin{array}{l}\text { Объем средств, привлеченных произво- } \\
\text { дными финансовыми инструментами }\end{array}$ & 0,5 & 0,5 & 0,3 & 0,7 & 4,2 & 1,9 & 1,7 \\
\hline $\begin{array}{l}\text { Объем средств, привлеченных выпуском } \\
\text { векселей, всего }\end{array}$ & 3,7 & 3,6 & 2,6 & 2,5 & 1,9 & 1,4 & 1,3 \\
\hline Bсего & 100 & 100 & 100 & 100 & 100 & 100 & 100 \\
\hline
\end{tabular}

Рассчитано по данным табл. 2.

Применительно к банковской деятельности различают инвестиционную политику и кредитную политику. За основу различия берется инициатор процесса: сама кредитная организация, или стороннее лицо - заемщик. В первом случае имеет место инвестиционная политика, во втором - кредитная политика. Исходя из такого подхода, под инвестиционной политикой банков понимают только их вложения в ценные бумаги, в валюту, в депозиты. Обратимся к словарным терминам.

Коротко, под инвестициями понимается размещение капитала с целью получения прибыли. Под инвестициями также понимаются денежные средства (ценные бумаги, имущество, имущественные права), вкладываемые в объект какого-либо вида деятельности в целях получения дохода и достижения положительного социального эффекта. Инвестиционная деятельность предполагает вложение инвестиций, или инвестирование, и совокупность практических действий по реализации инвестиций. Соответственно, инвестиционная политика - это политика капиталовложений, ориентированная на достижение определенных целей ${ }^{3}$. Значит, не учитывая специфику деятельности субъекта инвестиционной политики, все средства, размещаемые кредитными организациями с целью извлечения прибыли, можно считать инвестициями.

Подробно теоретические аспекты процесса банковского кредитования и инвестиционной банковской деятельности рассматриваются в трудах отечественных ученых О. И. Лаврушина [3], В. А. Боровковой [4], Г. Н. Белоглазовой, Л. П. Кроливецкой [5].

Рассматривая инвестиционную политику, проводимую российскими кредитными организациями в 2013-2015 гг., можно выявить определенную закономерность динамики суммы размещенных кредитными организациями средств, а именно: снижение в 1-м полугодии каждого анализируемого года и рост во 2-м полугодии (табл. 4). Снижение объема размещенных средств в 1-м полугодии 2013 и 2014 гг. было небольшим (в пределах 1,5 трлн р.), тогда как в 1-м полугодии 2015 г. снижение составило почти 9 трлн р. Во 2-м полугодии 2013 г. общий объем размещенных средств вырос более, чем на 9 трлн р., а во 2 -м полугодии 2014 г. рост составил 16,6 трлн р. - самый большой за рассматриваемый период. За 2-е полугодие 2015 г. объем размещенных средств показал прирост на 12,5 трлн р. В целом, за три года наблюдается повышательная тенденция, общий прирост размещенных средств составил $52,9 \%$.

${ }^{3}$ URL : http//:www.bibliotekar.ru/finansovyi-slovar.

\section{Baikal Research Journal}

электронный научный журнал Байкальского государственного университета 
Таблица 4

Средства, размещенные российскили кредитныли организацияли, 2013-2016 г2., трлн р.

\begin{tabular}{|c|c|c|c|c|c|c|c|}
\hline \multirow[t]{2}{*}{ Размещенные средства } & \multicolumn{2}{|c|}{2013} & \multicolumn{2}{|c|}{2014} & \multicolumn{2}{|c|}{2015} & 2016 \\
\hline & 01.01 & 01.07 & 01.01 & 01.07 & 01.01 & 01.07 & 01.01 \\
\hline $\begin{array}{l}\text { Кредиты: } \\
\text { р. } \\
\text { иностранная валюта }\end{array}$ & $\begin{array}{r}32,89 \\
25,86 \\
7,03 \\
\end{array}$ & $\begin{array}{r}36,18 \\
27,30 \\
8,88 \\
\end{array}$ & $\begin{array}{r}38,77 \\
29,84 \\
8,93 \\
\end{array}$ & $\begin{array}{r}42,06 \\
32,67 \\
9,39 \\
\end{array}$ & $\begin{array}{l}49,07 \\
34,89 \\
14,18\end{array}$ & $\begin{array}{l}48,42 \\
33,72 \\
14,70\end{array}$ & $\begin{array}{l}54,27 \\
35,18 \\
19,09\end{array}$ \\
\hline $\begin{array}{l}\text { Кредиты малому и среднему бизнесу, а } \\
\text { также индивидуальным предприятиям: }\end{array}$ & 6,95 & 3,61 & 8,06 & 3,83 & 7,61 & 2,46 & 5,46 \\
\hline р. & $\begin{array}{l}6,77 \\
0,18\end{array}$ & $\begin{array}{l}3,49 \\
0,12\end{array}$ & $\begin{array}{l}7,76 \\
0,30\end{array}$ & $\begin{array}{l}3,68 \\
0,15\end{array}$ & $\begin{array}{l}7,19 \\
0,42\end{array}$ & $\begin{array}{l}2,33 \\
0,13\end{array}$ & $\begin{array}{l}5,08 \\
0,38\end{array}$ \\
\hline $\begin{array}{l}\text { Жилищные кредиты физическим лицам: } \\
\text { р. } \\
\text { иностранная валюта }\end{array}$ & $\begin{array}{r}1,07 \\
1,05 \\
0,018 \\
\end{array}$ & $\begin{array}{r}0,37 \\
0,36 \\
0,009 \\
\end{array}$ & $\begin{array}{r}1,41 \\
1,39 \\
0,019 \\
\end{array}$ & $\begin{array}{r}0,79 \\
0,79 \\
0,004 \\
\end{array}$ & $\begin{array}{r}1,82 \\
1,81 \\
0,013 \\
\end{array}$ & $\begin{array}{r}0,47 \\
0,47 \\
0,003 \\
\end{array}$ & $\begin{array}{r}1,17 \\
1,16 \\
0,006 \\
\end{array}$ \\
\hline $\begin{array}{l}\text { Ипотечные жилищные кредиты физиче- } \\
\text { ским лицам: }\end{array}$ & 1,04 & 0,55 & 1,36 & 0,77 & 1,76 & 0,46 & 1,14 \\
\hline $\begin{array}{l}\text { р. } \\
\text { иностранная валюта }\end{array}$ & $\begin{array}{r}1,02 \\
0,015\end{array}$ & $\begin{array}{r}0,54 \\
0,007\end{array}$ & $\begin{array}{r}1,34 \\
0,015 \\
\end{array}$ & $\begin{array}{r}0,77 \\
0,004\end{array}$ & $\begin{array}{r}1,75 \\
0,011 \\
\end{array}$ & $\begin{array}{r}0,46 \\
0,002 \\
\end{array}$ & $\begin{array}{r}1,14 \\
0,004 \\
\end{array}$ \\
\hline $\begin{array}{l}\text { Вложения в долговые и долевые ценные } \\
\text { бумаги }\end{array}$ & 6,64 & 7,06 & 7,55 & 7,67 & 9,51 & 9,53 & 11,58 \\
\hline $\begin{array}{l}\text { Вложения в производные финансовые } \\
\text { инструменты }\end{array}$ & 0,16 & 0,19 & 0,18 & 0,32 & 2,30 & 1,20 & 1,26 \\
\hline $\begin{array}{l}\text { Сумма учтенных векселей: } \\
\text { р. } \\
\text { иностранная валюта }\end{array}$ & $\begin{array}{r}0,40 \\
0,31 \\
0,091 \\
\end{array}$ & $\begin{array}{r}0,38 \\
0,28 \\
0,098 \\
\end{array}$ & $\begin{array}{r}0,27 \\
0,22 \\
0,052 \\
\end{array}$ & $\begin{array}{r}0,23 \\
0,20 \\
0,025\end{array}$ & $\begin{array}{r}0,22 \\
0,19 \\
0,029 \\
\end{array}$ & $\begin{array}{r}0,17 \\
0,13 \\
0,044 \\
\end{array}$ & $\begin{array}{r}0,20 \\
0,13 \\
0,074 \\
\end{array}$ \\
\hline Прочие вложения & 0,33 & 0,34 & 0,35 & 0,45 & 0,43 & 0,47 & 0,57 \\
\hline Всего & 49,48 & 48,68 & 57,95 & 56,12 & 72,72 & 63,18 & 75,65 \\
\hline
\end{tabular}

Составлено по: URL : http://www.cbr.ru/publ/BBS/Bbs1312r.pdf; URL : http://www.cbr.ru/publ/ BBS/Bbs1412r.pdf; URL : http://www.cbr.ru/publ/BBS/Bbs1512r.pdf; URL : http://www.cbr.ru/publ/ BBS/Bbs1602r.pdf.

В составе кредитов организациям, физическим лицам и кредитным организациям заметное место занимают кредиты физическим лицам (см. табл. 4). Динамику их размера и доли в кредитах можно проследить в табл. 5 , в которой прослеживается абсолютный рост объема рублевых кредитов физическим лицам до 2015 г. В течение 2015 г. объем рублевых кредитов физическим лицам снизился на 0,6 трлн р. Удельный вес рублевых кредитов рос в течение 2013 г. Начиная с 2014 г. удельный вес неуклонно снижается.

Таблица 5

Кредиты физическил лицал

\begin{tabular}{|c|c|c|c|c|c|c|c|c|}
\hline \multirow{2}{*}{$\begin{array}{c}\text { Валюта } \\
\text { кредитов }\end{array}$} & \multirow[t]{2}{*}{ Показатель } & \multicolumn{2}{|c|}{2013} & \multicolumn{2}{|c|}{2014} & \multicolumn{2}{|c|}{2015} & 2016 \\
\hline & & 01.01 & 01.07 & 01.01 & 01.07 & 01.01 & 01.07 & 01.01 \\
\hline \multirow[t]{2}{*}{$\begin{array}{l}\text { Кредиты } \\
\text { в рублях }\end{array}$} & $\begin{array}{l}\text { Кредиты организациям, физическим ли- } \\
\text { цам, кредитным организациям, трлн р. }\end{array}$ & 25,86 & 27,30 & 29,84 & 32,67 & 34,89 & 33,72 & 35,18 \\
\hline & $\begin{array}{l}\text { В том числе кредиты физическим лицам: } \\
\text { трлн р. } \\
\% \\
\end{array}$ & $\begin{array}{r}7,49 \\
29,00 \\
\end{array}$ & $\begin{array}{r}8,34 \\
31,30 \\
\end{array}$ & $\begin{array}{r}9,72 \\
32,60\end{array}$ & $\begin{array}{l}10,42 \\
31,90 \\
\end{array}$ & $\begin{array}{l}11,03 \\
31,60\end{array}$ & $\begin{array}{l}10,47 \\
31,00\end{array}$ & $\begin{array}{l}10,40 \\
29,60\end{array}$ \\
\hline \multirow[t]{2}{*}{$\begin{array}{l}\text { Кредиты } \\
\text { в валюте }\end{array}$} & $\begin{array}{l}\text { Кредиты организациям, физическим ли- } \\
\text { цам, кредитным организациям, трлн р. }\end{array}$ & 7,03 & 8,88 & 8,93 & 9,39 & 14,18 & 14,70 & 19,09 \\
\hline & $\begin{array}{l}\text { В том числе кредиты физическим лицам: } \\
\text { трлн р. } \\
\%\end{array}$ & $\begin{array}{l}0,24 \\
3,40\end{array}$ & $\begin{array}{l}0,25 \\
2,80\end{array}$ & $\begin{array}{l}0,24 \\
2,70\end{array}$ & $\begin{array}{l}0,22 \\
2,30\end{array}$ & $\begin{array}{l}0,30 \\
2,10\end{array}$ & $\begin{array}{l}0,26 \\
1,80\end{array}$ & $\begin{array}{l}0,29 \\
1,50\end{array}$ \\
\hline
\end{tabular}

Составлено по: URL : http://www.cbr.ru/publ/BBS/Bbs1312r.pdf; URL : http://www.cbr.ru/publ/ BBS/Bbs1412r.pdf; URL : http://www.cbr.ru/publ/BBS/Bbs1512r.pdf; URL : http://www.cbr.ru/publ/ BBS/Bbs1602r.pdf.

\section{Baikal Research Journal}


Объем валютных кредитов физическим лицам имеет по годам волнообразную динамику, однако их удельный вес снижается в течение всех трех лет. Если абсолютный размер валютных кредитов на 1 января 2016 г. по сравнению с 1 января 2013 г. почти не изменился, то их удельный вес снизился больше, чем в 2 раза.

В феврале 2016 г. Банк России зафиксировал рост во всех сегментах розничного кредитования. Ту же тенденцию отмечают в Объединенном кредитном бюро, Национальном бюро кредитных историй и в Национальном рейтинговом агентстве. Есть надежда на сохранение повышательной динамики кредитования физических лиц на протяжении текущего года ${ }^{4}$.

Волнообразную динамику показывают кредиты малым и средним предприятиям, а также индивидуальным предпринимателям.

Как заметила Э. Набиуллина на XXVII съезде Ассоциации российских банков, по итогам 2015 г. объемы кредитования малого и среднего бизнеса (МСБ) снизились на $5 \%$. Чтобы создать банкам новые стимулы для кредитования МСБ, регулятор увеличил лимит по специальному инструменту по кредитам МСБ на 25 млрд р. и снизил требования к оценке рискованности этих кредитов на $75 \%{ }^{5}$. В своей статье В. Ю. Далбаева, длительное время занимающаяся вопросами кредитования предприятий МСБ, отметила меры Банка России по совершенствованию нормативной базы, необходимые для стимулирования развития МСБ [6].

Вложения в долговые (облигации) и долевые (акции) ценные бумаги растут на протяжении всех трех анализируемых лет. Самый большой прирост инвестиций в ценные бумаги произошел за 2-е полугодие 2014 г. Он составил $24 \%$. Немногим меньше $(21,5 \%)$ оказался прирост инвестиций в ценные бумаги во 2 -м полугодии 2015 г. В результате размещение средств в ценные бумаги на 1 января 2016 г. превысило данные на 1 января 2013 г. в 1,7 раза. Следует отметить, что росли вложения как в облигации, так и в акции. При этом вложения в акции делятся на инвестиции с целью получения дохода, прежде всего спекулятивного, и на инвестиции с целью участия в капитале акционерных обществ. Проведенный анализ показал, что рост вложений в акции на протяжении всего исследуемого периода происходил за счет инвестиций с целью участия в дочерних и зависимых компаниях.

Можно предположить, что при нынешнем состоянии фондового рынка кредитные организации уходят от агрессивной политики и смещают свой инвестиционный интерес в сторону более консервативных операций.

Инвестиции кредитных организаций в производные финансовые инструменты росли, начиная со 2-го полугодия 2014 г. до 2-го полугодия 2015 г. На 1 января 2015 г. их прирост составил $78 \%$, тогда как на 1 июля 2015 г. инвестиции в ПФИ выросли в 7 раз. Подтверждаются наши выводы, сделанные ранее в статье о том, что в условиях нарастающих рисков финансовые игроки обращают большее внимание на возможности срочного рынка [7].

Суммарные инвестиции кредитных организаций в векселя снижаются. Объем учтенных векселей на 1 января 2016 г. составил 50 \% от соответствующего показателя 1 января 2013 г. При этом, если объем учтенных рублевых векселей снижается неуклонно, потеряв за три года 58 \%, то объем учтенных валютных векселей имеет по полугодиям волнообразную тенденцию, поэтому его трехлетние потери составили $19 \%$.

Рост в течение анализируемых лет показывают прочие вложения. В соответствующей строке табл. 4 показаны средства, вложенные кредитными организациями в компании, не являющиеся акционерными обществами. Поскольку официальные

${ }^{4}$ URL : https//bankir.ru/novosti/20160401.

${ }^{5}$ URL : https//bankir.ru/novosti/20160407.

\section{Baikal Research Journal}

электронный научный журнал Байкальского государственного университета 
статистические данные не выделяют цели данных вложений, будем считать, что эти инвестиции направлены как на получение дохода, так и на участие в капитале. За три года объем прочих вложений вырос почти на $73 \%$. Значительный прирост $(28,6$ \% ) произошел в 1 -м полугодии 2014 г. Дальнейший рост наблюдался в течение всего 2015 г.: на $9 \%$ за 1-е полугодие и на $21 \%$ за 2 -е полугодие.

Суммарные кредиты (табл. 6 , стр. $2-5$ ) в составе размещенных средств занимают наибольший удельный вес - от 82 до $85 \%$. В их составе наибольший удельный вес занимают кредиты организациям, физическим лицам и кредитным организациям — от 67 до $77 \%$. Их удельный вес на 1 января 2016 г. на $5 \%$ превысил удельный вес на начало 2013 г.

Таблица 6

Структура средств, размещенных российскими кредитными организациями, в 2013-2016 22., \%

\begin{tabular}{|l|r|r|r|r|r|r|r|}
\hline \multirow{2}{*}{ Размещенные средства } & \multicolumn{2}{|c|}{2013} & \multicolumn{2}{|c|}{2014} & \multicolumn{2}{|c|}{2015} & 2016 \\
\cline { 2 - 8 } & 01.01 & 01.07 & 01.01 & 01.07 & 01.01 & 01.07 & 01.01 \\
\hline Кредиты & 66,5 & 74,3 & 66,9 & 74,9 & 67,5 & 76,6 & 71,7 \\
\hline $\begin{array}{l}\text { Кредиты среднему и малому бизнесу и индиви- } \\
\text { дуальным предприятиям }\end{array}$ & 14,0 & 7,4 & 13,9 & 6,8 & 10,5 & 3,9 & 7,2 \\
\hline Жилищные кредиты физическим лицам & 2,2 & 0,8 & 2,4 & 1,4 & 2,5 & 0,7 & 1,5 \\
\hline $\begin{array}{l}\text { Ипотечные жилищные кредиты физическим } \\
\text { лицам }\end{array}$ & 2,1 & 1,1 & 2,4 & 1,4 & 2,4 & 0,7 & 1,5 \\
\hline Вложения в долговые и долевые ценные бумаги & 13,4 & 14,5 & 13,0 & 13,7 & 13,0 & 15,1 & 15,3 \\
\hline $\begin{array}{l}\text { Вложения в производные финансовые инстру- } \\
\text { менты }\end{array}$ & 0,3 & 0,4 & 0,3 & 0,6 & 3,2 & 2,0 & 1,7 \\
\hline Сумма учтенных векселей, всего & 0,8 & 0,8 & 0,5 & 0,4 & 0,3 & 0,3 & 0,3 \\
\hline Прочие вложения & 0,7 & 0,7 & 0,6 & 0,8 & 0,6 & 0,7 & 0,8 \\
\hline \multicolumn{1}{|l|}{ Всего } & 100 & 100 & 100 & 100 & 100 & 100 & 100 \\
\hline
\end{tabular}

Рассчитано по данным табл. 4.

Удельный вес кредитов предприятиям малого и среднего бизнеса снижается в 1-м полугодии каждого анализируемого года и растет во 2-м полугодии. В целом за три года их доля в размещенных средствах снизилась в 2 раза.

Аналогичную колебательную динамику показывает удельный вес жилищных кредитов физическим лицам и ипотечных жилищных кредитов физическим лицам - снижение в 1-м полугодии каждого года. Примечательно, что в течение 2-го полугодия 2013 и 2014 гг. удельный вес жилищных и ипотечных жилищных кредитов восстанавливался до первоначального уровня. Исключением стал 2015 г. Рост удельного веса жилищных и ипотечных жилищных кредитов во 2-м полугодии не смог компенсировать его снижение в 1-м полугодии. В результате доля жилищных и ипотечных жилищных кредитов физическим лицам на 1 января 2016 г. оказалась ниже того же показателя на 1 января 2013 г. на 0,7 и 0,6 \% соответственно.

На третьем месте в структуре всех инвестированных кредитными организациями средств находятся вложения в долговые и долевые ценные бумаги. Их удельный вес меняется от 13 до 15 \% , показывая по полугодиям 2013 и 2014 гг. то рост, то снижение. В течение 2015 г. удельный вес вложений в базовые ценные бумаги растет, в целом, за год на $2,3 \%$. По сравнению с 1 января 2013 г. рост данного показателя к началу 2016 г. составил около $2 \%$.

К началу 2015 г. в 10 раз вырос удельный вес вложений кредитных организаций в производные финансовые инструменты. Однако в течение 2015 г. при снизившихся объемах вложений (см. табл. 4), их доля снижалась, составив на 1 января 2016 г. $1,7 \%$ (это на 1,5 \% больше, чем на 1 января 2013 г.).

\section{Baikal Research Journal}


Удельный вес учтенных векселей в структуре инвестированных банками средств в течение трех лет демонстрирует понижательную динамику, которая соответствует динамике объема учтенных векселей (см. табл. 4). Причин этому может быть несколько. Во-первых, кредитные организации сократили выпуск векселей (см. табл. 2), что, соответственно, привело к сокращению численности клиентов, обращающихся к ним с вопросом об учете векселей. Во-вторых, векселя относятся к активам повышенной группы риска, и кредитные организации сокращают активные операции с ними с 2012 г., когда было введено в действие соответствующее решение регулятора, прямо влияющее на размеры резервов. В-третьих, альтернативное размещение средств - инвестиции в облигации, которые также являются долговыми ценными бумагами, но имеют значительные преимущества перед векселями. Это наличие процедуры государственной регистрации, а также преимущественно безналичная форма выпуска, что делает их намного надежнее и удобнее в использовании. Приведенные рассуждения подтверждаются расчетными данными (см. табл. 4 и 6 ).

Удельный вес прочих вложений значительных изменений в течение трех лет не претерпел, оставаясь на уровне $0,6-0,8 \%$.

Из проведенного анализа ресурсной и инвестиционной политики российских кредитных организаций можно сделать следующие выводы. Несмотря на введение экономических санкций против России отечественные банки за последние три года продолжили наращивать свою ресурсную базу. Собственный капитал банков за этот период вырос на $32 \%$, а привлеченные средства показали рост $69 \%$. В составе привлеченных средств наибольший рост (более, чем в 6 раз) показали средства, привлеченные производными финансовыми инструментами, хотя их удельный вес в структуре привлеченных средств составил на конец исследуемого периода всего около $2 \%$. Рост в $97 \%$ показали депозиты организаций и индивидуальных предпринимателей с долей в 36 \% в структуре привлеченных средств на начало 2016 г. Около 44 \% в привлеченных средствах занимают вклады физических лиц, которые за три года выросли на $63 \%$. Можно утверждать, что привлечение средств населения является центральным направлением ресурсной деятельности кредитных организаций.

Однако несмотря на ожидания, в текущем году наблюдается отток вкладов. В частности, по итогам марта 2016 г. совокупный отток вкладов на сумму около 460,5 млрд р. показали 454 банка. «Лидером» среди них оказался Сбербанк, следующими идут ВТБ 24 , Газпромбанк, Райффайзенбанк и банк ФК Открытие ${ }^{6}$ К Как видно, в первой пятерке находятся устойчивые кредитные организации. Из приведенных данных следует, что в кризисных условиях домохозяйства снижают накопления, а для тех средств, которые накапливаются, ищутся более высокие процентные ставки.

Использование ценных бумаг не играет большой роли в привлечении ресурсов. Удельный вес полученных от их продажи средств на 1 января 2016 г. составил 4,8 \% в сумме привлеченных средств. Средства от продажи депозитных и сберегательных сертификатов за три года выросли в 2,5 раза, однако их темпы прироста по годам снижались. Известно, что сберегательные сертификаты являются прямыми конкурентами вкладов, но отличаются от последних отсутствием страхования средств населения. С этой позиции сберегательные сертификаты более выгодны банкам и менее выгодны вкладчикам. Можно сказать, что действующее в настоящее время законодательство вложило в данный инструмент привлечения средств внутреннее противоречие.

${ }^{6}$ URL : https//bankir.ru/novosti/20160419.

\section{Baikal Research Journal}

электронный научный журнал Байкальского государственного университета 
Средства от продажи облигаций приросли за три года на $22 \%$, но их приток отличался неравномерностью, связанной с непростой ситуацией на фондовом рынке. Видимо, значимость этого инструмента привлечения ресурсов не вырастет, пока не стабилизуется финансово-экономический климат в стране.

Векселя оказались единственным инструментом кредитных организаций, показавшим за три года существенное снижение поступления ресурсов, в целом на $40 \%$.

Суммарные инвестиции кредитных организаций также росли. За три года прирост размещенных средств составил $53 \%$. Наибольший трехлетний прирост показали кредиты физическим лицам - 39 \% и кредиты юридическим лицам (организациям и кредитным организациям) - 35 \%. Незначительно выросли объемы жилищных и ипотечных жилищных кредитов. Объем кредитов предприятиям МСБ, напротив, упал за три года на 21,4 \% с итоговым двойным снижением удельного веса в сумме размещенных средств.

Вырос объем активных операций кредитных организаций на рынке ценных бумаг: почти в 2 раза вложения в долговые и долевые ценные бумаги и в 8 раз вложения в производные финансовые инструменты. Однако вложения в векселя (учет векселей) на начало 2016 г. сократились по сравнению с 1 января 2013 г. вдвое. В то же время крайне низким остается в стране инвестиционный кредит (капитальные вложения в экономику. - И.Д.). В 2015 г. он составил лишь 1,5 \% от банковских активов, величина (78 трлн р.) которых в 5 раз больше федерального бюджета. Инвестиционный кредит в России на душу населения в 9-12 раз меньше, чем в США и Германии, и в 4-6 раз меньше, чем в Китае и других развивающихся странах [8]. Российский фондовый рынок также не играет существенной роли в формировании инвестиций и в перетоке капитала из отрасли в отрасль [9].

Представляют интерес результаты деятельности коммерческих банков. Вопросами их анализа и оценки результативности занимаются такие специалисты, как Л. Г. Батракова [10], Е. П. ЖЖарковская [11]. Собственную методику расчета уровня эффективности деятельности банков разработали А. В. Верников и М. Е. Мамонов [12].

За рассматриваемый период объем прибыли российских кредитных организаций имеет тенденцию к снижению. Так, за 2013 г. прибыль снизилась на 2,0 \% , за 2014 г. снижение составило 40,7 \% , за 2015 г. - 67,4\% (табл. 7). Видно, что темп снижения прибыли по годам растет. На 1 января 2016 г. по сравнению с данными на 1 января 2013 г. прибыль снизилась в 5 раз, или на 81,0 \% .

Таблица 7

Финансовые результаты деятельности кредитных организаций

\begin{tabular}{|c|c|c|c|c|c|c|c|}
\hline \multirow[t]{2}{*}{ Финансовые результаты } & \multicolumn{2}{|c|}{2013} & \multicolumn{2}{|c|}{2014} & \multicolumn{2}{|c|}{2015} & 2016 \\
\hline & 01.01 & 01.07 & 01.01 & 01.07 & 01.01 & 01.07 & 01.01 \\
\hline $\begin{array}{l}\text { Объем прибыли/убытков } \\
\text { текущего года, млрд р. }\end{array}$ & 1011,89 & 491,39 & 993,59 & 451,39 & 589,14 & 51,49 & 191,97 \\
\hline $\begin{array}{l}\text { Объем прибыли по прибыль- } \\
\text { ным банкам, млрд р. }\end{array}$ & 1021,25 & 501,12 & 1012,25 & 486,64 & 853,24 & 307,93 & 735,80 \\
\hline $\begin{array}{l}\text { Удельный вес прибыльных } \\
\text { банков, \% }\end{array}$ & 94,20 & 86,20 & 90,50 & 76,90 & 84,90 & 73,80 & 75,40 \\
\hline $\begin{array}{l}\text { Объем убытков по убыточ- } \\
\text { ным банкам, } \\
\text { млрд р. }\end{array}$ & 9,36 & 9,73 & 18,67 & 35,25 & 264,10 & 256,44 & 543,84 \\
\hline $\begin{array}{l}\text { Удельный вес убыточных } \\
\text { банков, \% }\end{array}$ & 5,80 & 132,80 & 9,50 & 23,10 & 15,10 & 26,20 & 24,60 \\
\hline
\end{tabular}

\section{Baikal Research Journal}


Динамика прибыли прибыльных банков также имеет понижательную тенденцию, однако темпы снижения прибыли сокращаются. За 2013 г. их прибыль снизилась на $0,9 \%$, за 2014 г. снижение составило 15,7 \% , тогда как за 2015 г. прибыль показала снижение на 13,8 . Всего за три года прибыль прибыльных банков снизилась на 28,0 \%. Убытки убыточных банков показывают противоположную тенденцию - растут по годам, но с замедлением темпов роста. За 2013 г. объем убытков вырос в 2 раза, за 2014 г. - в 14 раз и за 2015 г. — в 2 раза. В целом за три года объем убытков убыточных банков вырос с 9,36 млрд р. до 543,84 млрд р., или примерно в 58 раз. Доля прибыльных банков сократилась на 20 \% , т. е. пятая часть российских банков за последние три года из прибыльных превратилась в убыточные. Соответственно, на 20 \% выросла доля убыточных банков.

По словам Э. Набиуллиной, за I кв. текущего года российские банки получили 107 млрд р. прибыли. По итогам 2016 г. ожидается рост банковской прибыли на сумму до 500 млрд р. Однако представляется достаточно сомнительным увеличение объема банковской прибыли за год более, чем в 2,6 раза после ускоряющегося трехлетнего снижения. Для сравнения проведем сопоставление объема прибыли с динамикой средств, привлеченных и размещенных банками (табл. 8).

Таблица 8

Динамика средств, привлеченных и размещенных российскими кредитными организациями, \%

\begin{tabular}{|c|r|r|r|}
\hline Год & Привлеченные средства & Размещенные средства & Объем прибыли \\
\hline 2013 & $+23,0$ & $+17,0$ & $-2,0$ \\
\hline 2014 & $+20,0$ & $+25,5$ & $-40,7$ \\
\hline 2015 & $+15,6$ & $+4,0$ & $-67,4$ \\
\hline
\end{tabular}

Рассчитано по данным табл. 2,4 и 7.

Из сравнительного анализа данных (см. табл. 7) можно сделать вывод о неэффективности функционирования банковской системы в течение рассматриваемого периода времени. Речь, прежде всего, идет о неэффективной инвестиционной деятельности (размещении средств). Среди общеизвестных причин сложившейся ситуации можно отметить следующие: невозврат выданных кредитов со стороны как физических, так и юридических лиц; вывод капитала через сомнительные операции; снизившуюся эффективность операций с ценными бумагами. Можно предположить и недостаточный профессионализм сотрудников аналитических отделов. Влияние перечисленных причин можно минимизировать, развивая в рамках банковского бизнеса такие направления, как риск-менеджмент и систему внутреннего контроля.

\section{Список использованной литературы}

1. Горчакова М. Е. Российские кредитные организации как эмитенты и инвесторы на рынке ценных бумаг : монография / М. Е. Горчакова, И. В. Дубовик. - Иркутск : Изд-во БГУЭП, 2011. - $80 \mathrm{c.}$

2. Дубовик И. В. Российские коммерческие банки как эмитенты на рынке акций / И. В. Дубовик // Проблемы мировой экономики: возможные вызовы для России. - Иркутск : Изд-во БГУЭП, 2012. - С. 40-47.

3. Банковское дело : учебник / под ред. О. И. Лаврушина. - 11-е изд., перераб. и доп. М. : КноРус, 2016. -800 c.

4. Банковское дело : учебник / под ред. В. А. Боровковой. - М. : Юрайт, 2016. -623 c.

5. Белоглазова Г. Н. Банковское дело. Организация деятельности коммерческого банка : учебник / Г. Н. Белоглазова, Л. П. Кроливецкая. - 3-е изд. - М. : Юрайт, 2016. - 546 с.

6. Далбаева В. Ю. Совершенствование нормативной базы ЦБ РФ с целью развития кредитования малого и среднего предпринимательства / В. Ю. Далбаева // Материалы 71-й еже-

\section{Baikal Research Journal}


годной научной конференции профессорско-преподавательского состава и докторантов, 23-й научной конференции аспирантов и 73-й научной конференции студентов и магистрантов / отв. ред. С. Ю. Куницына. - Иркутск : Изд-во БГУЭП, 2012. — С. 199-202.

7. Дубовик И. В. Срочный рынок ценных бумаг РФ в условиях финансового кризиса / И. В. Дубовик, А. М. Вильвер // Материалы 69-й ежегодной научной конференции профессорско-преподавательского состава и докторантов, 21-й научной конференции аспирантов и 71-й научной конференции студентов и магистрантов / отв. ред. С. Ю. Куницына. - Иркутск : Изд-во БГУЭП, 2010. - Ч. 1. - С. 76-82.

8. Аганбегян А. Г. Где взять деньги? / А. Г. Аганбегян // Аргументы и факты. — 2016. № 15 . - C. 10 .

9. Аганбегян А. Г. Размышления о финансовом форсаже (По мотивам книги «Финансовые стратегии модернизации экономики: мировая практика») / А. Г. Аганбегян // Деньги и кредит. - 2015. - № 8. - С. 5-10.

10. Батракова Л. Г. Экономический анализ деятельности коммерческого банка : учебник / Л. Г. Батракова. - М. : Логос, 2007. - 351 с.

11. Жарковская Е. П. Финансовый анализ деятельности коммерческого банка : учебник / Е. П. Жарковская. - 3-е изд., перераб. - М. : Омега-Л, 2015. - 378 с.

12. Верников А. В. Сравнительный анализ эффективности госбанков и частных банков в России: новые расчеты / А. В. Верников, М. Е. Мамонов // Деньги и кредит. — 2015. № 7. - C. 21-32.

\section{References}

1. Gorchakova M. E., Dubovik I. V. Rossiiskie kreditnye organizatsii kak emitenty i investory na rynke tsennykh bumag [Russian credit organizations as emitents and investors on security market]. Irkutsk, Baikal State University of Economics and Law Publ., 2011. 80 p.

2. Dubovik I. V. Russian commercial banks as emitents on share market. Problemy mirovoi ekonomiki: vozmozhnye vyzovy dlya Rossii [Problems of world economy: possible challenges for Russia]. Irkutsk, Baikal State University of Economics and Law Publ., 2012, pp. 40-47. (In Russian).

3. Lavrushin O. I. (ed.). Bankovskoe delo [Banking]. 11 ${ }^{\text {th }}$ ed. Moscow, KnoRus Publ., 2016. 800 p.

4. Borovkova V. A. (ed.). Bankovskoe delo [Banking]. Moscow, Yurait Publ., 2016. 623 p.

5. Beloglazova G. N., Krolivetskaya L. P. Bankovskoe delo. Organizatsiya deyatel'nosti kommercheskogo banka [Banking. Activity arrangement for commercial banks]. $3^{\text {rd }}$ ed. Moscow, Yurait Publ., 2016. 546 p.

6. Dalbayeva V. Yu. Improving the normative base of RF Central Bank with the view of developing crediting for small and medium businesses. In Kunitsyna (ed.). Materialy 71-i ezhegodnoi nauchnoi konferentsii professorsko-prepodavatel'skogo sostava i doktorantov, 23-i nauchnoi konferentsii aspirantov i 73-i nauchnoi konferentsii studentov $i$ magistrantov [Materials of 71-st Annual Scientific Conference of Academic Staff and Doctoral Students, 23-rd Scientific Conference of PhD Students and 73-rd Scientific Conference of Students and Master Degree Students]. Irkutsk, Baikal State University of Economics and Law Publ., 2012, pp. 199-202. (In Russian).

7. Dubovik I. V., Vil'ver A. M. Derivatives market of RF securities in terms of financial crisis. In Kunitsyna (ed.). Materialy 69-i ezhegodnoi nauchnoi konferentsii professorskoprepodavatel'skogo sostava i doktorantov, 21-i nauchnoi konferentsii aspirantov $i$ 71-i nauchnoi konferentsii studentov $i$ magistrantov [Materials of 69-th Annual Scientific Conference of Academic Staff and Doctoral Students, 21-st Scientific Conference of PhD Students and 71-st Scientific Conference of Students and Master Degree Students]. Irkutsk, Baikal State University of Economics and Law Publ., 2010, pr. 1, pp. 76-82. (In Russian).

8. Aganbegyan A. G. Where to get money? Argumenty $i$ fakty = Arguments and Facts, 2016, no. 15, p. 10. (In Russian).

9. Aganbegyan A. G. Reflections on Financial Boosting (on the Motives of the Book «Financial Strategies for Economic Modernisation: Global Practice»). Den'gi i kredit= Money and Credit, 2015, no. 8, pp. 5-10. (In Russian).

10. Batrakova L. G. Ekonomicheskii analiz deyatel'nosti kommercheskogo banka [Economic analysis of commercial bank activities]. Moscow, Logos Publ., 2007. 351 p.

11. Zharkovskaya E. P. Finansovyi analiz deyatel'nosti kommercheskogo banka [Financial analysis of commercial bank activities] $3^{\text {rd }}$ ed. Moscow, Omega-L Publ., 2015. 378 p.

\section{Baikal Research Journal}


12. Vernikov A. V., Mamonov M. E. Comparative Efficiency Analysis of State-Controlled and Private Banks in Russia: New Empirical Evidence. Den'gi i kredit = Money and Credit, 2015, no. 7, pp. 21-32. (In Russian).

\section{Информация об авторе}

Дубовик Ирина Владимировна - кандидат экономических наук, доцент, кафедра банковского дела и ценных бумаг, Байкальский государственный университет, 664003, г. Иркутск, ул. Ленина, 11, e-mail: ivd@bk.ru.

\section{Author}

Irina V. Dubovik - PhD in Economics, Associate Professor, Chair of Banking and Securities, Baikal State University, 11 Lenin St., 664003, Irkutsk, Russian Federation; e-mail: ivd@bk.ru.

\section{Библиографическое описание статьи}

Дубовик И. В. Ресурсная инвестиционная политика российских кредитных организаций в условиях экономических санкций / И. В. Дубовик // Baikal Research Journal. - 2016. T. 7, № 4. - DOI : 10.17150/2411-6262.2016.7(4).5.

\section{Reference to article}

Dubovik I. V. Resource-based investment policy of Russian credit organizations in terms of economic sanctions. Baikal Research Journal, 2016, vol. 7, no. 4. DOI : 10.17150/24116262.2016.7(4).5. (In Russian).

\section{Baikal Research Journal}

